Jurnal

\title{
Leadless Cardiac Pacemakers: Where are we?
}

\author{
Albert Sudharsono, Dicky A. Hanafy, Yoga Yuniadi
}

Departemen Kardiologi dan Ke-dokteran Vaskular, Universitas Indonesia / Rumah Sakit Jantung dan Pembuluh Darah Harapan Kita, Indonesia
The development of health technology benefits in the treatment of heart rhythm abnormalities. Cardiac pacemakers with nonsurgical methods plays a critical role in the management of patients with heart rhythms disorders. The discovery of a leadless pacemaker provides many benefits compared to conventional pacemaker where the device can be implanted by transcatheter delivery. Various studies have been done and still continued to monitor the efficacy and safety of this device. In principle, Indonesia is ready to participate in the advance technology of leadless pacemaker. National Health Covarage policy will play an important role in this new technology in the future.

(J Kardiol Indones. 2016;37:47-56)

Keywords: Leadless pacemaker, Atrioventricular Block, Single Chamber Pacemake 


\title{
Alat Pacu Jantung Tanpa Kabel
}

\author{
Albert Shudarsono, Dicky A. Hanafy, Yoga Yuniadi
}

\begin{abstract}
Perkembangan teknologi kesehatan memberikan kemajuan dalam tatalaksana kelainan irama jantung. Alat pacu jantung memegang peranan penting dalam tatalaksana pasien dengan kelainan irama jantung dengan metode nonbedah. Penemuan alat pacu jantung tanpa kabel memberikan banyak manfaat dibanding alat pacu jantung konvensional dimana alat tersebut ditanam melalu kateter. Berbagai studi telah dlakukan dan masih berlangsung untuk memantau manfaat dan keamanan alat tersebut. Pada prinsipnya Indonesia siap berpartisipasi dalam teknologi terbaru alat pacu jantung tanpa kabel, kebijakan jaminan kesehatan nasional memegang peranan penting dalam penggunaan terbaru ini di masa yang akan datang.
\end{abstract}

(J Kardiol Indones. 2016;37:47-56)

Kata kunci: Alat Pacu Jantung tanpa Kabel, Blok Atrioventrikular, Pacu Jantung Kamar Tunggal

\section{Pendahuluan}

$\mathrm{M}$ esin alat pacu jantung pertama dibuat oleh seorang anestesiolog Mark Lidwell dari Australia pada tahun 1928, Lidwell menggunakan jarum yang dimasukan ke dalam ventrikel jantung dan dialiri listrik secara bertahap pada bayi yang terlahir dengan henti jantung. ${ }^{1}$ Pada tahun 1932, Albert Hyman berhasil menemukan alat yang dinyatakan sebagai alat pacu jantung buatan yang pertama, alat tersebut berhasil digunakan pada manusia, dengan berat $7,3 \mathrm{~kg}$ alat tersebut dapat mengalirkan 30, 60, hingga 120 impuls per menit dan harus diputar dengan tangan setiap 6 menit. $^{2}$ John Hopps pada tahun 1950 berdasarkan pengamatan yang dilakukan pada seorang ahli bedah Wilfred Gordon Bigelow di Kanada.

Alamat Korespondensi

dr. Dicky A. Hanafy, SpJP. Divisi Aritmia, Departemen Kardiologi dan Kedokteran Vaskular, FKUI dan Pusat Jantung Nasional Harapan Kita, Jakarta. E-mail: yogay136@gmail.com
Alat pacu jantung pertama tersebut terletak di luar tubuh dengan kabel penghantar yang dimasukan ke dinding dada menuju jantung. ${ }^{3}$ Prosedur ini sangat menyakitkan pasien pada saat itu dan dapat mencetuskan terjadinya fibrilasi ventrikel.

Pada tanggal 8 oktober 1958 alat pacu jantung pertama sukses di implantasikan oleh Senning dan Elmqvist pada pasien dengan gangguan konduksi impuls jantung melalui prosedur bedah. ${ }^{1}$ Pada saat itu alat pacu jantung merupakan sebuah alat generator yang diletakan di luar tubuh di sambungkan dengan kabel yang ditanam di jantung dengan prosedur operasi. Meskipun bisa membantu menyelamatkan nyawa pasien, saat itu banyak terdapat komplikasi yang terjadi di kemudian hari, seperti singkatnya masa kerja baterai, kegagalan kabel penghantar dan infeksi yang banyak terjadi karena saat itu generator terletak di luar tubuh. Pasien pertama yang mendapatkan terapi pemasangan alat pacu jantung tersebut bernama Arne Larsson, mengalami operasi pemasangan berbagai jenis alat pacu jantung sebanyak 
26 kali hingga meninggal pada tahun $2001 .{ }^{1}$ Melihat kekurangan tersebut berbagai ahli mengembangkan berbagai generator yang dapat di program agar dapat mengatur laju jantung dan keluaran yang diinginkan tanpa harus melakukan prosedur invasif dan memperpanjang masa kerja baterai hingga lebih dari 1 tahun pada saat itu.

Dalam 50 tahun terakhir teknologi terus berkembang, banyak terjadi perubahan-perubahan yang revolusioner seperti pemasangan dapat dilakukan di 2 tempat pada jantung sehingga memungkinkan pengaturan sinkronisasi pada atrioventrikular, laju jantung responsif, defibrilator kardiak implantabel, dan terapi resinkronisasi jantung dengan defibrilator atau tanpa defibrilator. Selain itu masa kerja baterai pada saat ini bisa bertahan hingga 10 tahun tergantung dari besarnya tenaga yang dikeluarkan oleh generator akibat penyakit yang mendasari.

Meskipun sudah banyak kemajuan dan perkembangan, beberapa hambatan dan komplikasi tidak jarang dijumpai. Komplikasi akibat pemasangan terus menjadi hal yang perlu dipertimbangkan seperti pneumothorax dan hematoma pada fase akut, kegagalan kabel atau terputusnya kabel dan infeksi pada kantung generator pada fase sub akut dan kronik. Ketika terjadi proses infeksi, satu-satunya penanganan yang harus dilakukan adalah penarikan seluruh generator dan kabel penghantar yang berdampak pada mahalnya biaya yang harus dikeluarkan dan komplikasi lanjutan yang memrlukan penanganan khusus.

Melihat berbagai komplikasi yang dapat ditimbulkan serta tingginya biaya yang harus dikeluarkan untuk mengatasi hal tersebut. Pada tahun 2013 diumumkan penemuan mengenai teknologi terbaru alat pacu jantung tanpa kabel penghantar. Hal ini terbukti sangat efektif dalam mengatasi infeksi yang ditimbulkan pada kantung tempat pemasangan. Uji coba pemasangan pada manusia dilakukan pada akhir tahun 2014 yang dilakukan oleh 2 perusahaan besar produsen alat pacu jantung. ${ }^{4,5}$

Namun, perlu diingat bahwa pada setiap alat yang baru diperkenalkan selalu terdapat kekurangan, studi mengenai kelayakan dan keamana alat tersebut juga sempat dihentikan menyusul laporan perforasi pada 6 orang pasien yang berujung dengan kematian pada 2 pasien. ${ }^{6}$ Setelah penyelidikan lebih lanjut, untuk memastikan komplikasi bukan diakibatkan karena alat tersebut, penelitian telah kembali dialnjutkan meskipun FDA masih belum memberikan izin terkait alat ini.
Selain kelebihan, alat ini juga memiliki kekurangan sebagai contoh; alat ini hanya bisa memberikan penggunaan di satu ruangan jantung yaitu ventrikel kanan, ketidaktersediaan pemantauan jarak jauh, serta sensor status cairan yang belum tersedia. Meskipun demikian alat ini memberikan harapan terhadap perkembangan alat elektronik kardiovaskular implan di masa mendatang.

\section{Studi Keamanan Pada Hewan Percobaan}

Berbagai studi mengenai keamanan, efektifitas, dan prosedur pemasangan telah dilakukan dalam perkembangan alat pacu jantung tanpa kabel. Alat pacu jantung tanpa kabel pertama kali dipasang pada hewan coba anjing pada tahun 1970 , berukuran $8 \times 18 \mathrm{~mm}$ dipacu sebanyak 100x/menit selama 66 hari, dan tidak ditemukan komplikasi saat itu. ${ }^{7}$ Namun, pada perkembanganya alat yang dimotori dengan tenaga nuklir tersebut tidak bisa digunakan karena alasan keamanan alat dan singkatnya masa kerja baterai.

Pada tahun 1991 alat pacu jantung yang diujicoba menggunakan 3 baterai berkekuatan 1.5 $\mathrm{V}$. Namun, alat pacu jantung tersebut tidak memiliki kemampuan sensing sehingga pada percobaan tersebut hanya dapat digunakan mode VOO. Mode VOO tersebut memiliki penggunaan terbatas dan biasanya digunakan hanya pada prosedur operasi untuk menghindari sensing akibat arus elektrik yang dicetuskan oleh elektrokauter. Sehingga alat tersebut tidak disarankan untuk percobaan lanjut pada manusia, meskipun angka keberhasilannya cukup baik pada hewan coba. ${ }^{8}$

Pada tahun 1999, Goto dkk. menemukan konsep berupa automatic power generating system. Sistem tersebut mengkonversi energi kinetik menjadi energi listrik dan ditanam pada ventrikel kanan. Energi kinetik yang dihasilkan oleh ventrikel kanan menjadi sumber energi untuk mengaktivasi alat tersebut.?

Pada tahun 2006, Echt dkk. menggunakan gelombang suara sebagai sumber energi. Sumber suara diberikan dari dinding dada dan mencapai elektroda yang tertanam pada miokard. Alat tersebut mengubah energi gelombang suara menjadi energi listrik $^{10}$ dan memberikan pemacuan. Pemacuan berhasil dilakukan pada lebih dari 30 tempat di atrium kanan dan ventrikel dengan gelombang suara. ${ }^{11}$ Penelitian tersebut diperkuat oleh Lee 
dkk. menunjukkan bahwa alat pacu jantung tanpa kabel dapat ditanam pada 84 tempat dalam jantung dengan menggunakan gelombang suara sebagai sumber energi. ${ }^{12}$

Penelitian yang dilakukan oleh Koruth dkk. pada tahun 2015 mengevaluasi implan alat pacu jantung tanpa kabel pada ventrikel kanan di hewan coba domba. Pemacuan menunjukkan keberhasilan pada 10 dari 11 kasus percobaan dalam periode 90 hari. ${ }^{13}$ Penelitian itu diperkuat dengan studi oleh Sperzel dkk. yang menanam alat pacu jantung tanpa kabel pada ventrikel kanan di hewan coba domba, namun studi tersebut lebih mengevaluasi tentang proses pengambilan kembali alat pacu jantung yang sudah ditanam. Penelitian ini menyimpulkan bahwa alat implan dapat diangkat kembali jika memang diperlukan. ${ }^{6}$

\section{Perkembangan Alat Pacu Jantung Saat Ini}

Saat ini terdapat dua Alat Pacu Jantung tanpa Kabel yang dipakai dan digunakan. Pertama, Nanostim yang dibuat Saint Jude Medical, dengan ukuran yang lebih kecil dari baterai AAA dengan dimensi panjang $4 \mathrm{~cm}$, lebar $6 \mathrm{~mm}$, berat 2 gram, dan dapat diletakkan pada otot jantung dengan menggunakan kateter $18 \mathrm{~F}$ yang diinsersi melalui vena femoralis menuju ventrikel kanan dan terfiksasi pada dinding otot jantung. Alat tersebut dapat dilepas dan direposisi sesuai dengan kebutuhan. ${ }^{4,14}$
Kedua, Micra Transcatheter Pacing System (TPS) dari Medtronic Inc. yang disebut sebagai pacemaker terkecil di dunia dengan dimensi lebar $7 \mathrm{~mm}$, panjang $26 \mathrm{~mm}$, dengan berat 2 gram. Saat ini studi dengan besar sampel 780 pasien masih dalam uji coba. TPS diinsersi dengan kateter ukuran 23F. Namun, perlu diingat bahwa TPS tidak dapat dipindahkan saat kekuatan baterai sudah akan habis. Sehingga, alat TPS baru perlu diinsersi dan ditanam pada lokasi yang dekat dengan TPS yang sudah tertanam sebelumnya., ${ }^{15}$ Alat ini tidak disarankan untuk pasien dengan usia muda.

Adapun, Wireless Cardiac Stimulation system (WiCS-LV) yang menggunakan gelombang suara yang ditransmisikan oleh generator yang ditanam secara subkutaneous dinding dada dan elektroda penerima kekuatan ditanam pada dinding ventrikel kiri jantung yang mengkonversikan energi suara menjadi energi elektrik sehingga dapat memacu jantung. ${ }^{16}$ Sebagai pembanding dengan kedua alat pacu jantung sebelumnya, alat ini digunakan sebagai Terapi Sinkronisasi Jantung saat dipasang dengan pacu jantung kovensional ventrikel kanan sehingga kedua ventrikel akan berkontraksi secara simultan. Keunggulan lain dari alat ini adalah dapat dipasang pada endokard sehingga lebih baik dibanding pemasangan pada epikard yang dilakukan pada alat terapi sinkronisasi jatung konvensional. Hal tersebut karena pemasangan pada endokard bersifat lebih fisiologis dan dapat meningkatkan respon klinis pasien pada penggunaan terapi resinkronisasi jantung. ${ }^{12,17}$
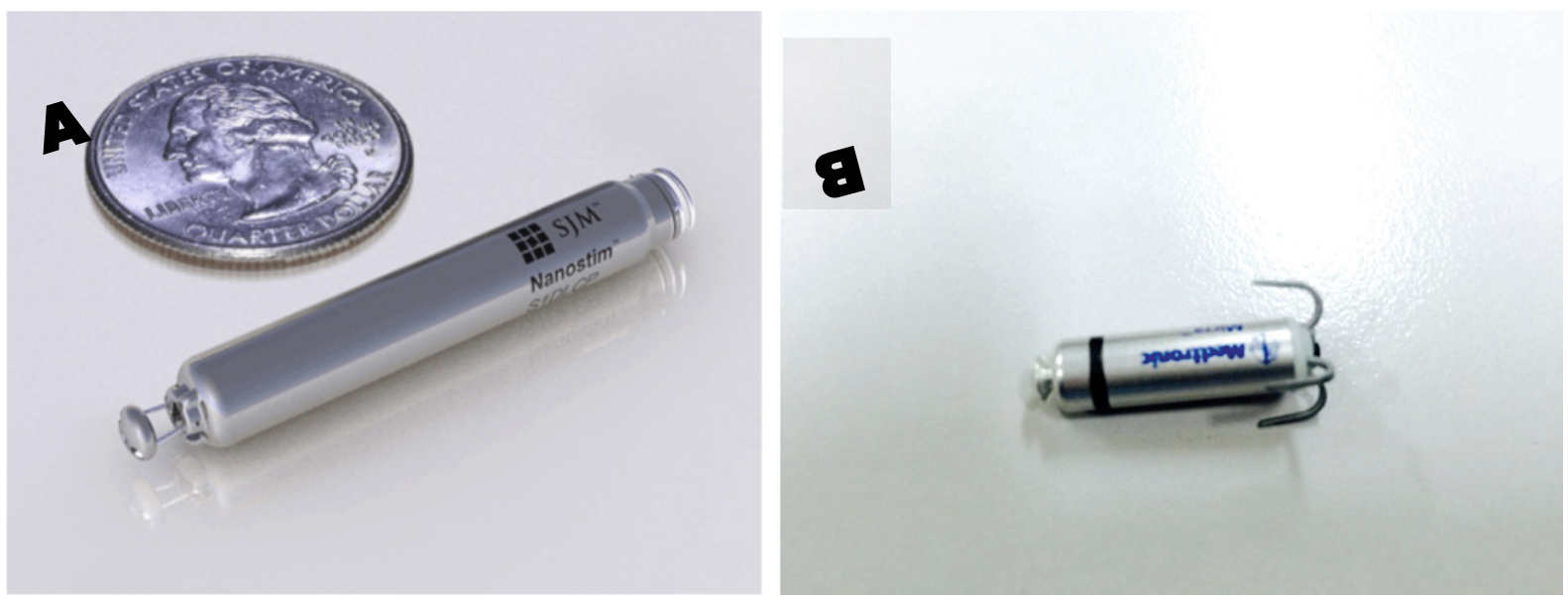

Gambar 1. Alat Pacu jantung tanpa Kabel. (A) Nanostim, (B) Micra 
A
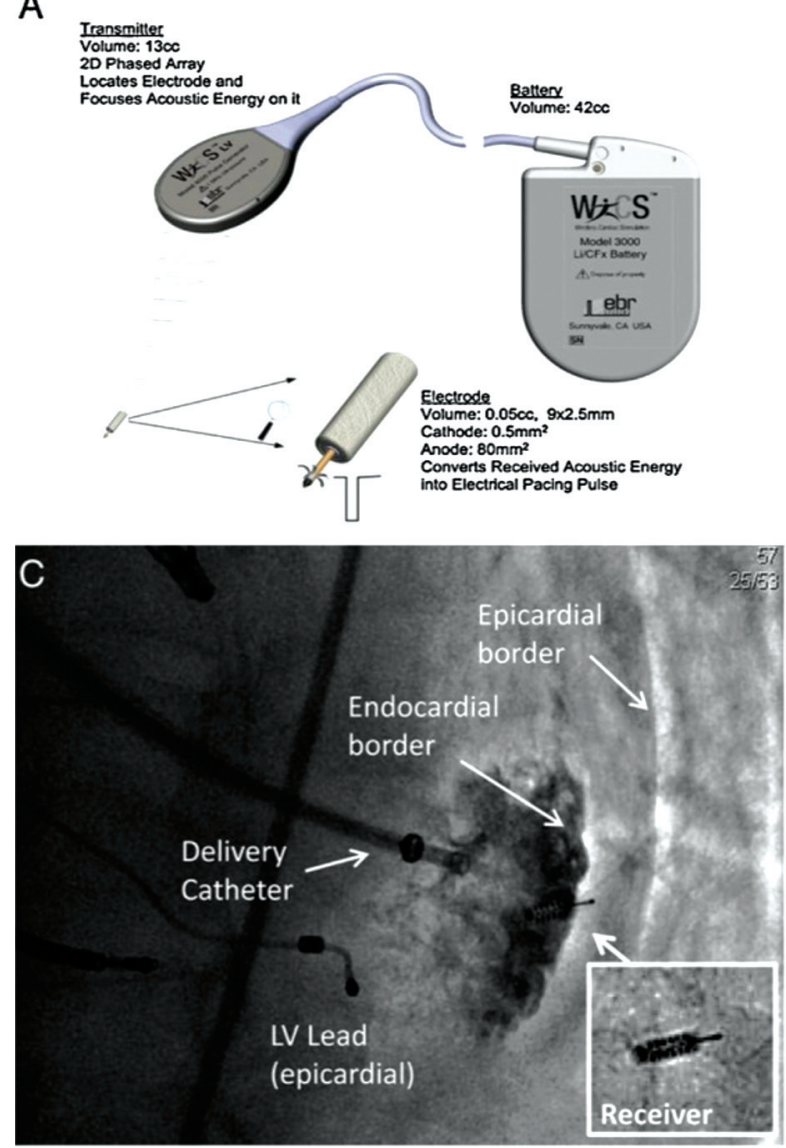

B
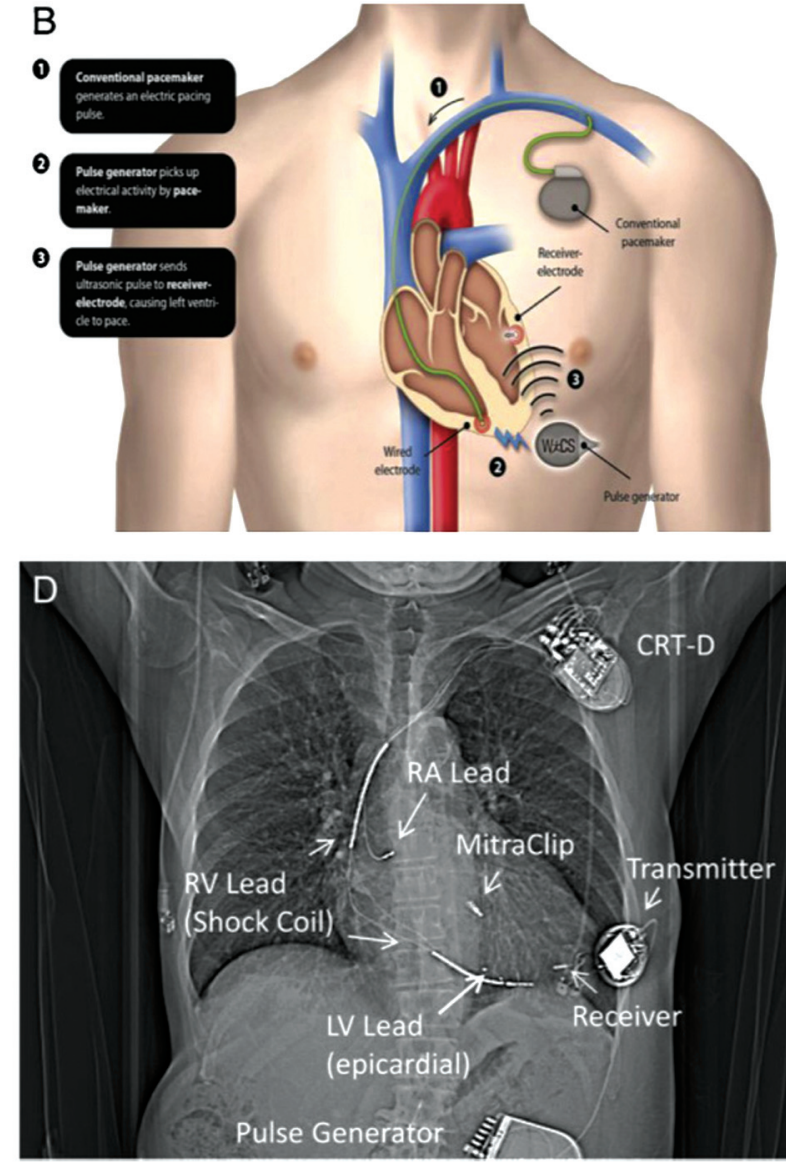

Gambar 2. (A) Teknologi WiCS-LV, Piezoelectric mengirimkan gelombang suara yang dikonversi menjadi energi mekanikal dikeluarkan sebagai impuls listrik. (B) WiCS-LV dapat ditanamkan bersama dengan alat pacu jantung, defibrilator kardioverter implan, maupun terapi resinkronisasi jantung. (C) Pencitraan dengan bimbingan floroskopi dengan kontras di dinding ventrikel kiri. (D) Posisi Terapi sinkronisasi jantung di regio subclavicula, Mitral clip, generator WiCS, penerima gelombang, dan generator pulse. (diadopsi dari "First-in-man implantation of leadless ultrasoundbased cardiac stimulation pacing system: novel endocardial left ventricular resynchronization therapy in heart failure patients" oleh Auricchio dkk ${ }^{16}$ )

\section{Studi Mengenai Alat Pacu Jantung Tanpa Kabel}

Pada prinsipnya Alat Pacu Jantung tanpa Kabel merupakan sebuah kemajuan terbaru pada teknologi pacu jantung. Studi kelayakan, efektifitas, dan keamanan masih dalam pemantauan. Leadless Trial yang dilakukan oleh Reddy dkk merupakan studi pertama mengenai kelayakan alat pacu jantung tanpa kabel ini, studi ini merupakan sebuah studi uji acak tidak terkontrol, prospektif dan melibatkan lebih dari 1 center meliputi 3 Rumah sakit di Eropa. Sebanyak 33 pasien dilibatkan dalam studi ini, indikasi pemasangan paling banyak disebabkan Atrial Fibrilasi permanen dengan blok Atrioventrikular (67\%), diikuti oleh blok Atrioventrikular derajat 2 atau 3 disertai angka komorbid yang tinggi 18\% dan sinus bradikardi dengan sinus pause yang jarang atau sinkop yang tidak diketahui sebesar $15 \% .{ }^{4}$

Penilaian mengenai alat pacu jantung tersebut dilakukan dalam rentang waktu selama 90 hari (reddy) yang dilanjutkan oleh Knops dkk hingga 1 tahun setelah pemasangan. Komponen awal yang dinilai berupa efek samping paska pemasangan baik akut maupun kronik, performa elektriksitas, aktifasi sensor respon laju jantung. Komponen lanjut yang 
dinilai berupa karakteristik performans alat tersebut seperti pacing tresholds, pascing impedance, cell voltage, amplitudo gelombang $\mathrm{R}$, presetasi pacing dan kumulatif cell charge. Selain itu pada pasien tertentu dilakukan tes 6-minute walk pada pemantauan 2 minggu setelah pemasangan. ${ }^{6}$

Selama pemantauan, sebanyak 2 dari 33 pasien tersebut tidak dapat diikutsertakan pada studi ini. Pada pasien pertama, pasien dengan riwayat atrial fibrilasi respon lambat dan infark emboli pada ginjal mengalami cardiac tamponade pada proses pemasangan sehingga harus mengalami operasi yang berakhir dengan kematian akibat infark arteri cerebral 5 hari setelah pemasangan, sedangkan pada pasien kedua pasien, pasien dengan fugsi ventrikel kiri yang buruk disertai blok atrioventrikular derajat 2 diharuskan pemasangan ICD pada 7 hari paska pemasangan Alat Pacu Jantung tanpa Kabel karena sinkop berulang, pada pemeriksaan lengkap menunjukan monomorfik ventrikular takikardia dengan episode sinkop. ${ }^{4}$

Pada 31 pasien (100\%) yang terus mendapatkan follow up hingga 1 tahun pemasangan, dilaporkan terdapat $8(26 \%)$ pasien yang memerlukan pemasangan ulang, sebanyak 3 pasien memerlukan pemasangan ulang sebanyak 1 kali, 3 pasien sebanyak 2 kali dan 2 pasien sebanyak 3 kali pemasangan ulang. Dalam 1 tahun pemantauan paska pemasangan tidak ditemui komplikasi akibat pemasangan alat pacu jantung tanpa kabel ini. Pada bulan ke 3 hingga 12, sebanyak 6 pasien (19\%) dilaporkan kembali dirawat di rumah sakit. Sebanyak 2 pasien dilaporkan menderita atrial fibrilasi rapid respon akibat gagal jantung kiri, namun saat pengukuran alat pacu jantung tanpa kabel dilakukan alat tersebut bekerja dengan optimal tanpa kendala.

Selain memantau komplikasi yang dapat timbul akibat pemasangan, performa alat pacu jantung tanpa kabel juga dinilai. Penurunan nilai ambang, impedansi, dan peningkatan gelombang $\mathrm{R} 1$ hari setelah pemasangan terus diukur per 3 bulan selama 1 tahun. Didapatkan hasil rata-rata nilai ambang sebesar $0.40 \pm 0.26 \mathrm{~V}$ dan $0.43 \pm 0.30 \mathrm{~V}$; amplitudo gelombang $\mathrm{R}$ sebesar $10.6 \pm 2.6 \mathrm{mV}$ dan $10.3 \pm 2.2$ $\mathrm{mV}$; dan impedansi sebesar $625 \pm 205 \underline{\Omega}$ and 627 $\pm 209 \underline{\Omega}$. Perubahan kekuatan nilai ambang tidak melebihi $0,25 \mathrm{~V}$ pada observasi per 3 bulan hingga 1 tahun, dimana performa alat ini memberikan hasil yang memuaskan.

Pada tahun 2014, studi kelayakan alat pacu jantung tanpa kabel kembali dilanjutkan dengan Leadless II Trial dimana pada penelitian ini 504 pasien dari 526 pasien berhasil dilakukan pemasangan alat pacu jantung tanpa kabel ini. Luaran primer dari studi tidak acak tersamar dengan analisis intention to treat menunjukkan efficacy dari alat pacu jantung tanpa kabel mencapai 90,0\% (IK 95\% 86,2-93,2, p=0.007) dan keamanan mencapai 93,3\% (IK 95\% 89,9-95,9, p>0,001) pada 270 dari 300 pasien yang direkrut. Hasil tersebut menunjukkan alat pacu jantung tanpa kabel terlihat superior dibandingkan dengan alat pacu jantung konvensional. Namun, tetap perlu diperhatkan bahwa studi oleh Reddy, dkk ini tidak secara langsung membandingkan alat pacu jantung tanpa kabel dengan alat pacu jantung konvensional. Selain itu, perlu diperhatikan juga adanya komplikasi serius yang terjadi pada $6,7 \%$ dari 526 pasien selama pemantauan 6 bulan. Komplikasi serius yang paling banyak terjadi adalah device dislodgement with percutaneous retrieval $(1,7 \%)$, perforasi kardiak $(1,3 \%)$, dan peningkatan nilai ambang pacu yang memerlukan percutaneous retrieval dan pemasangan ulang alat $(1,3 \%)$.

Studi lainnya yang dilakukan oleh Reynolds dkk menggunakan alat pacu jantung tanpa kabel dengan alat yang berbeda yang digunakan oleh Redy dkk. Pada penelitian ini alat pacu jantung tanpa kabel menggunakan Medtronic Micra. Studi yang dilakukan Reynolds dkk, meliputi center dan populasi yang lebih luas daripada yang dilakukan Reddy dkk, penelitian ini mencakup 56 center yang tersebar di 19 negara seperti Amerika Utara, Eropa, Asia, Austraia dan Afrika. ${ }^{15}$

Alat tersebut berhasil dipasang pada 719 dari 725 pasien (99.2\%). Menggunakan kesintasan kaplanmeier untuk menganalisis angka primary safety end point didapatkan sebesar 96\% (KI 95\%, p<0,001) pada 6 bulan paska pemasangan. Namun, perlu diperhatikan bahwa selama pemantauan terdapat 28 komplikasi yang terjadi pada 25 pasien dari 725 pasien. Komplikasi yang terjadi paling banyak berupa perlukaan pada jantung 11 kasus, perlukaan pada tempat penusukan jarum (lipat paha), 2 kasus thromemboli dan 2 kasus kegagalan pemacuan. Sebanyak 8 kasus lainya, masing-masing disebabkan oleh berbagai hal dimana 1 dari 8 kasus tersebut berakhir dengan kematian.

Sebanyak 297 pasien yang diikut sertakan pada penelitian ini dalam analisis awal keamanan alat, sebanyak 292 pasien memberikan hasil yang memuaskan 6 bulan paska pemasangan (98,3\%, KI 95\%). Hal ini ditunjukan dengan ambang pacu yang tidak melebih $2.0 \mathrm{~V}$ dan peningkatan tidak melebihi $1.5 \mathrm{~V}$ selama 6 
bulan pemantauan dibandingkan dengan harapan angka keberhasilan sebesar $80 \%$. $(\mathrm{p}<0,001)$. Pada penelitian ini tidak ditemukan komplikasi berupa infeksi sistemik, pneumothorax, dislodgement, atau emboli alat pacu. Pada studi ini didapatkan 1 kasus dimana harus dilakukan pengambilan alat akibat kegagalan fungsi alat sehingga dilakukan pemasangan kembali 17 hari setelah pemasangan. ${ }^{15}$

Pada analisis Studi post Hoc ini juga membandingkan dengan penelitian yang menggunakan alat pacu jantung trans vena. Sebanyak 725 pasien dalam studi ini dianalisis sebagai kasus dibandingkan dengan 2667 pasien yang mendapatkan alat pacu jantung trans vena dianalisis sebagai kontrol. Selama 6 bulan pemantauan, pasien dengan alat pacu jantung tanpa kabel mendapatkan komplikasi lebih sedikit dibandingkan pada pasien kontrol (Hazard ratio 0,49\%; KI 95\%; $\mathrm{p}=0.001)^{15}$

Meskipun menunjukan berbagai kelebihan, penelitian yang dilakukan Reynolds dkk tidak dapat dibandingkan secara langsung dengan penelitian yang dilakukan Reddy dkk, namun jika dilihat secara statistik tidak ditemukan perbedaan bermakna dari kedua alat tersebut seperti yang ditunjukan pada tabel 1.

Pada sebuah laporan kasus, dilaporkan penggunaan alat pacu jantung tanpa kabel pada pasien usia dewasa muda dengan kelainan jantung bawaan berupa transposisi arteri besar dengan dextrokardia. Pada pemeriksaan EKG didapatkan pemanjangan gelombang PR, QRS sempit dan blok atrioventrikular bertahap, dimana keadaan ini memerlukan pemasangan alat pacu jantung. Pada kasus tersebut dilakukan pemasangan perkutaneus alat pacu jantung tanpa kabel di endokardial. Laporan ini memberikan harapan pemasangan alat pacu jantung pada pasien dengan kelainan jantung bawaan yang rumit. ${ }^{18}$
Pada penderita gagal jantung disertai blok berkas cabang kiri, diperlukan pemasangan terapi sinkronisasi jantung ${ }^{19}$, namun terdapat beberapa kesulitan dalam pemasangan yang mungkin terjadi seperti kesulitan akses vena, tersumbatnya sinus koronarius, stabilitas kabel, dan stimulasi nervus frenikus. Pada tahun 2013, percobaan pertama pemasangan WiCS-LV dilakukan dengan melibatkan 3 pasien, dimana ketiga pasien tersebut berada dalam kondisi memerlukan pemasangan terapi sinkronisasi jantung. Hasil sudi tersebut menunjukan bahwa alat tersebut berhasil dipasang kepada ketiga pasien tersebut, tidak terdapat komplikasi dalam pemasangan dan pada pemantauan menunjukan terjadinya perbaikan kelas fungsional menurut NYHA, ambang pacu berkisar antara $0.7-1.0 \mathrm{~V}$ pada $0.5 \mathrm{~ms}$; dan kenaikan fraksi ejeksi ventrikel kiri dari $23.7 \pm 3.4 \%$ menjadi $39 \pm 6.2 \%(\mathrm{P}<0.017) .{ }^{16}$

Melihat hasil studi di atas, maka dilakukan studi berikut nya dengan skala yang lebih besar yang dinamakan WiSE-CRT yang dilakukan Auricchio dkk, dengan teknologi WiCS-LV khususnya pada pasien gagal jantung terbukti memberikan hasil yang cukup baik. ${ }^{20}$ Studi tersebut melaporkan 17 pasien penderita gagal jantung yang memenuhi syarat untuk dilakukan pemasangan terapi sinkronisasi jantung, namun tidak memberikan hasil yang memuaskan pada pemasangan konvensional. Hasil pemantauan yang diberikan sangat cukup memuaskan dimana gelombang QRS paska pemasangan memendek dari bulan pertama pemasangan $(-41 \mathrm{~ms} ; \mathrm{p}=0.002)$ dan 6 bulan pemasangan $(-42 \mathrm{~ms} ; \mathrm{p}=0.0011)$. Sebanyak $66 \%$ penderita mengalami perbaikan kelas fungsional jantung dan peningkatan fraksi ejeksi jantung pada 6 bulan paska pemasangan $(\mathrm{p}<0.01) .{ }^{20}$

Studi Wise-CRT mengenai pemasangan dan efektifitas dihentikan karena alasan keamanan, studi

Tabel 1. Perbandingan Pemasangan Alat Pacu Jantung Tanpa Kabel ${ }^{14,15}$

\begin{tabular}{|c|c|c|c|c|c|c|}
\hline Studi & $\begin{array}{l}\text { Jumlah } \\
\text { pasien }\end{array}$ & $\begin{array}{c}\text { Angka kesuksesan } \\
\text { implantasi }\end{array}$ & $\begin{array}{c}\text { Komplikasi } \\
\text { Mayor }\end{array}$ & $\begin{array}{c}\text { Perforasi atau } \\
\text { Efusi }\end{array}$ & Dislokasi alat & $\begin{array}{l}\text { Adekuasi pacu } \\
\text { selama } 6 \text { bulan }\end{array}$ \\
\hline Leadless trial II & 526 & $95.8 \%$ & $6.5 \%$ & $1.5 \%$ & $1.1 \%$ & $90.0 \%$ \\
\hline Micra Transcathter Pacing Study & 726 & $99.2 \%$ & $4.0 \%$ & $1.6 \%$ & $0 \%$ & $98.3 \%$ \\
\hline
\end{tabular}

Tabel 2. Hasil Studi Wise-CRT ${ }^{20}$

\begin{tabular}{lcccccc}
\hline Studi & $\begin{array}{c}\text { Jumlah } \\
\text { pasien }\end{array}$ & $\begin{array}{c}\text { Jumlah kesuksesan } \\
\text { implantasi }\end{array}$ & $\begin{array}{c}\text { Komplikasi } \\
\text { Mayor }\end{array}$ & $\begin{array}{c}\text { Perforasi atau } \\
\text { Efusi }\end{array}$ & $\begin{array}{c}\text { Kegagalan } \\
\text { pacu }\end{array}$ & $\begin{array}{c}\text { Adekuasi pacu selama } \\
\text { 6 bulan }\end{array}$ \\
\hline Wise- CRT & 17 & $13(76.5 \%)$ & $4(23.5 \%)$ & $3(17.625 \%)$ & $1(5,875 \%)$ & $92 \%$ \\
\hline
\end{tabular}


tersebut menunjukan angka keberhasilan yang tidak memuaskan, alat tersebut berhasil dipasang pada 13 pasein dengan tingkat keberhasilan $76 \%$ dan pada $3(18 \%)$ pasien terjadi komplikasi serius paska pemasangan seperti efusi perikardial karena manipulasi kabel dan kawat penghantar, bahkan menyebabkan 1 kematian akibat dari komplikasi ini. Selain itu, sebanyak 2 pasien (11\%) memerlukan prosedur perbaikan posisi akibat hilangnya kontak pemacuan biventrikular dan usia baterai yang secara mendadak habis. ${ }^{20,21}$

\section{Alat Pacu Jantung di Indonesia}

Diperkirakan lebih dari 1 juta orang mendapat terapi pemasangan alat pacu jantung di dunia ${ }^{17}$, jumlah ini terus meningkat pertahun yang diperkirakan akibat bertambahnya usia dan berbagai kondisi penyakit yang mendasari

Indonesia merupakan sebuah negara kepulauan dengan total penduduk lebih dari 250 juta jiwa dengan angka kesakitan yang diakibatkan oleh penyakit tidak menular termasuk didalamnya penyakit kardiovaskular seperti gagal jantung dan penyakit jantung koroner yang menyentuh $1.8 \%$ atau sebesar 3,18 juta penduduk dari total populasi. ${ }^{22}$ Untuk kelainan irama jantung, hingga saat ini Indonesia belum memiliki data yang pasti. Masih diperlukan penelitian lebih lanjut mengenai jumlah pasti kelainan irama jantung.

Pemasangan alat pacu jantung pertama kali dilakukan di Indonesia pada tahun 1974 di Jakarta, saat itu alat pacu jantung pertama kali dilakukan pada pasien berusia 9 tahun bernama Dewi Sartika. Setelah itu hingga saat ini lebih dari 30 ahli pemasangan alat pacu jantung yang tersebar di seluruh Indonesia dengan pemasangan lebih dari 688 unit yang dipasang dalam setiap tahunnya. Rumah Sakit tempat pemasangan masih terpusat di beberapa rumah sakit besar sekitar pulau Jawa dengan total lebih dari 20 rumah sakit. ${ }^{23}$

Dalam perkembangan aritmia dan alat pacu jantung, meskipun tergolong muda Indonesia terus mengalami perkembangan setiap tahunya. Hal ini dapat dilihat dari jumlah pemasangan alat pacu jantung yang terus bertambah dari dari tahun 2012 sebanyak 371 alat hingga 2015 berkembang menjadi 717 alat baru. Hal ini juga diikuti dengan bertambahnya semakin banyak ahli aritmia di Indonesia setiap tahun nya. Diperkirakan akan terdapat lebih dari 1000 pemasangan alat pacu jantung baru tiap tahun pada 2020 kelak. $^{23}$

Perkembangan alat pacu jantung tanpa kabel tentunya menarik untuk diikuti, melihat berkembangnya alat pacu jantung di indonesia saat ini, namun beberapa catatan perlu diberikan mengingat teknologi ini belum sepenuhnya direkomendasikan oleh organisasi irama jantung di dunia, dimana studi keamanan alat ini masih dalam pemantauan sehingga belum mendapatkan rekomendasi oleh ahli aritmia di organisasi dunia. ${ }^{14,15}$

Dalam beberapa tahun belakangan ini, Indonesia mulai menerapkan Program "Jaminan Kesehatan Nasional” dengan unit pelaksana BPJS. Program ini bertujuan seluruh rakyat Indonesia dapat memperoleh sistem pelayanan yang merata untuk semua bidang kesehatan termasuk kesehatan jantung. Hingga saat ini, BPJS belum dapat mengakomodir pemasangan alat pacu jantung tanpa kabel ini, dikarenakan formularium yang belum diajukan.

Pemasangan alat pacu jantung sendiri diindakasikan paling banyak akibat blok Atrioventrikular derajat tinggi dan sindroma sinus sakit. ${ }^{24}$ Hingga saat ini pemasangan menggunakan alat pacu jantung tanpa kabel masih terbatas untuk kamar tunggal, tentunya hal ini menjadi perhatian khusus mengingat pada blok atrioventrikular derajat tinggi tidak terdapat disosiasi nodal atrioventrikular sehingga pemasangan harus meliputi kamar ganda untuk mengsinkronisasikan nodal atrioventrikular. ${ }^{19}$

Mengacu pada penelitian yang dilakukan oleh Mond HG negara berkembang lebih banyak menggunakan alat pacu jantung kamar tunggal, karena biaya alat pacu jantung kamar ganda lebih banyak dari alat pacu jantung kamar tunggal. ${ }^{25}$ Walaupun pada keadaan blok atrioventrikular dan sindroma sinus sakit pemacuan kamar ganda memberikan hasil dan keluaran yang lebih baik. ${ }^{24}$ Sementara itu biaya yang dikeluarkan untuk pemasangan alat pacu jantung permanen kamar ganda lebih sedikit dibanding biaya yang harus dikeluarkan untuk alat pacu jantung tanpa kabel.

Terlepas dari kekurangan yang ada, alat pacu jantung tanpa kabel memberikan secercah harapan bagi tatalaksana kelainan irama jantung di Indonesia. Pemasangan alat pacu jantung tanpa kabel dilakukan melalui vena femoralis, sehingga pada prakteknya alat pacu jantung tanpa kabel dapat dilakukan oleh spesialis jantung intervensi yang jumlah nya mulai merata di Indonesia. Saat ini fasilitas ruang katetrisasi pun sudah mulai tersebar di Rumah Sakit seluruh Indonesia, sehingga alat pacu jantung tanpa kabel dapat dipasang di ruangan kateterisasi biasa tanpa memerlukan sterilitas khusus seperti pada pemasangan alat pacu 
jantung biasa, dimana sterilitas sangat ditekankan. Lama perawatan pun akan lebih pendek, karena setelah prosedur selesai pasien diperbolehkan untuk pulang.

\section{Kesimpulan}

Pada studi-studi yang telah dilakukan menunjukan bahwa alat pacu jantung tanpa kabel aman dan bermanfaat. Penelitian yang lebih besar dan waktu lama ,masih diperlukan untuk memantau keamanan dan penggunaan alat ini. Indonesia sebagai negara besar dan berkembang siap berpartisipasi dalam studi tersebut.

\section{Daftar Pustaka}

1. Aquilina O. A brief history of cardiac pacing. Images in paediatric cardiology. 2006;8(2):17-81.

2. Ward C, Henderson S, Metcalfe NH. A short history on pacemakers. International journal of cardiology. 2013;169(4):244-8.

3. Hopps JA. The development of the pacemaker. Pacing Clin Electrophysiol. 1981;4(1):106-8.

4. Reddy VY, Knops RE, Sperzel J, Miller MA, Petru J, Simon J, et al. Permanent leadless cardiac pacing: results of the LEADLESS trial. Circulation. 2014;129(14):1466-71.

5. Ritter P, Duray GZ, Steinwender C, Soejima K, Omar R, Mont L, et al. Early performance of a miniaturized leadless cardiac pacemaker: the Micra Transcatheter Pacing Study. Eur Heart J. 2015;36(37):2510-9.

6. Knops RE, Tjong FV, Neuzil P, Sperzel J, Miller MA, Petru J, et al. Chronic performance of a leadless cardiac pacemaker: 1-year follow-up of the LEADLESS trial. J Am Coll Cardiol. 2015;65(15):1497-504.

7. Spickler JW, Rasor NS, Kezdi P, Misra SN, Robins KE, LeBoeuf C. Totally self-contained intracardiac pacemaker. J Electrocardiol. 1970;3(3-4):325-31.

8. Vardas PE, C. P, E. M, F. P, C. T. A miniature pacemaker introduced intravenously and implanted endocardially preliminary findingsfrom an experimental study. Eur J CPE. 1991;1:2730.

9. Goto H, Sugiura T, Harada Y, Kazui T. Feasibility of using the automatic generating system for quartz watches as a leadless pacemaker power source. Medical \& biological engineering \& computing. 1999;37(3):377-80.

10. Sperzel J, Khairkhahan A, Ligon DA, Zaltsberg S. Feasibility, efficacy and safety of percutaneous retrieval of a leadless cardiac pacemaker in an in vivo bovine model. Europace : European pacing, arrhythmias, and cardiac electrophysiology : journal of the working groups on cardiac pacing, arrhythmias, and cardiac cellular electrophysiology of the European Society of Cardiology. 2013;15((Suppl 2 )):859.

11. Echt DS, Cowan MW, Riley RE, Brisken AF. Feasibility and safety of a novel technology for pacing without leads. Heart Rhythm. 2006;3(10):1202-6.

12. Lee KL, Lau CP, Tse HF, Echt DS, Heaven D, Smith W, et al. First human demonstration of cardiac stimulation with transcutaneous ultrasound energy delivery: implications for wireless pacing with implantable devices. J Am Coll Cardiol. 2007;50(9):877-83.

13. Koruth JS, Rippy MK, Khairkhahan A, Ligon DA, Hubbard CA, St Goar F, et al. Feasibility and efficacy of percutaneously delivered leadless cardiac pacing in an in vivo ovine model. J Cardiovasc Electrophysiol. 2015;26(3):322-8.

14. Reddy VY, Exner DV, Cantillon DJ, Doshi R, Bunch TJ, Tomassoni GF, et al. Percutaneous Implantation of an Entirely Intracardiac Leadless Pacemaker. N Engl J Med. 2015;373(12):112535.

15. Reynolds D, Duray GZ, Omar R, Soejima K, Neuzil P, Zhang $S$, et al. A Leadless Intracardiac Transcatheter Pacing System. N Engl J Med. 2015.

16. Auricchio A, Delnoy PP, Regoli F, Seifert M, Markou T, Butter C, et al. First-in-man implantation of leadless ultrasound-based cardiac stimulation pacing system: novel endocardial left ventricular resynchronization therapy in heart failure patients. Europace : European pacing, arrhythmias, and cardiac electrophysiology : journal of the working groups on cardiac pacing, arrhythmias, and cardiac cellular electrophysiology of the European Society of Cardiology. 2013;15(8):1191-7.

17. Seriwala HM, Khan MS, Munir MB, Riaz IB, Riaz H, Saba S, et al. Leadless pacemakers: A new era in cardiac pacing. Journal of cardiology. 2016;67(1):1-5.

18. Wilson DG, Morgan JM, Roberts PR. "Leadless" pacing of the left ventricle in adult congenital heart disease. International journal of cardiology. 2016.

19. European Society of C, European Heart Rhythm A, Brignole M, Auricchio A, Baron-Esquivias G, Bordachar P, et al. 2013 ESC guidelines on cardiac pacing and cardiac resynchronization therapy: the task force on cardiac pacing and resynchronization therapy of the European Society of Cardiology (ESC). Developed in collaboration with the European Heart Rhythm Association (EHRA). Europace : European pacing, arrhythmias, and cardiac electrophysiology : journal of the working groups on cardiac pacing, arrhythmias, and cardiac cellular electrophysiology of the European Society of Cardiology. 2013;15(8):1070118.

20. Auricchio A, Delnoy PP, Butter C, Brachmann J, Van Erven L, Spitzer S, et al. Feasibility, safety, and short-term outcome of 
leadless ultrasound-based endocardial left ventricular resynchronization in heart failure patients: results of the wireless stimulation endocardially for CRT (WiSE-CRT) study. Europace : European pacing, arrhythmias, and cardiac electrophysiology : journal of the working groups on cardiac pacing, arrhythmias, and cardiac cellular electrophysiology of the European Society of Cardiology. 2014;16(5):681-8.

21. Miller MA, Neuzil P, Dukkipati SR, Reddy VY. Leadless Cardiac Pacemakers: Back to the Future. J Am Coll Cardiol. 2015;66(10):1179-89.

22. RI BK. Laporan Nasional 2013. Riset Kesehatan Dasar
(RISKESDAS) 2013. 2013.

23. Raharjo SB. The Current Status of Cardiac Electrophysiology in Indonesia. InaHRS News. 2015(7):1-4.

24. Dretzke J, Toff WD, Lip GY, Raftery J, Fry-Smith A, Taylor R. Dual chamber versus single chamber ventricular pacemakers for sick sinus syndrome and atrioventricular block. Cochrane Database Syst Rev. 2004(2):CD003710.

25. Mond HG, Proclemer A. The 11th world survey of cardiac pacing and implantable cardioverter-defibrillators: calendar year 2009--a World Society of Arrhythmia's project. Pacing Clin Electrophysiol. 2011;34(8):1013-27. 